\title{
COMPETITIVENESS AND DETERMINANT OF INDONESIAN PROCESSED COCOA DEMAND IN THE AANZFTA FRAMEWORK
}

\author{
Renery Yemima*1 \\ Tanti Novianti ${ }^{2}$
}

1,2IPB University, Indonesia

\begin{abstract}
Indonesia is one of the biggest producer of cacao beans in the world. Export tariff policy on cacao bean and countries trade agreement was expected can increase the processed of cacao export. This research aims to analyze the competitiveness and the determinants of which affect the processed cacao export in AANZFTA Region countries. Based on RCA anaylsis, the processed cacao has been comparative advantage, and its EPD analysis show that Indonesia's processed cacao mostly in falling star and retreat condition. The result of regression analysis panel data showed that the export of cacao paste was affected significantly by exchange rate, Indonesia's export competitiveness, and free trade area policy. Cacao butter was affected significantly by exchange rate, Indonesia's export competitiveness, and free trade area policy. Cacao powder was affected significantly by gross domestic product total, exchange rate, Indonesia's export competitiveness, and free trade area policy.
\end{abstract}

Keywords: Cacao, EPD, Export, RCA

\section{ABSTRAK}

Indonesia merupakan salah satu negara produsen kakao terbesar di dunia. Kebijakan tariff biji kakao dan Kerjasama perdagangan diharapkan dapat meningkatkan permintaan ekspor kakao olahan. Penelitian ini bertujuan untuk menganalisa daya saing dan faktor-faktor yang mempengaruhi ekspor kakao olahan di Negara-negara AANZFTA. Berdasarkan analisa RCA, Indonesia memiliki keunggulan komparatif dan berdasarkan analisis EPD, ekspor kakao olahan Indonesia menduduki posisi falling star dan retreat. Hasil regresi data panel menunjukkan ekspor kakao pasta dipengaruhi secara signifikan oleh nilai tukar, daya saing kakao olahan Indonesia, dan kebijakan perdagangan. Ekspor kakao butter dipengaruhi secara signifikan oleh PDB total, nilai tukar, dan kebijakan perdagangan, dan Ekspor kakao powder dipengaruhi secara signifikan oleh PDB total, nilai tukar, daya saing kakao olahan Indonesia, dan kebijakan perdagangan.

Kata Kunci: Kakao, EPD, Ekspor, RCA

JEL: F1; N50

Pendahuluan

Sebagai negara agraris Indonesia memiliki potensial untuk menjadikan sektor pertani-
Tanggal Masuk: 3 April 2020

Tanggal Direvisi: 10 Mei 2020

Tanggal Diterima:

20 Juni 2020

Tersedia Online:

25 Juni 2020

${ }^{*}$ Korespondensi:

Renery Yemima

E-mail:

tantinovianti@apps.ipb.ac.id

JIET (Jurnal Ilmu Ekonomi Terapan) p-ISSN: 2541-1470; e-ISSN: 2528-1879 DOI: $10.20473 /$ jiet.v5i1.19627

Open access under a Creative Commons Attribution-ShareAlike 4.0 International 
an sebagai penunjang ekonomi dan pendapatan nasional. Sub sektor perkebunan merupakan salah satu sub sektor yang memberikan kontribusi besar, dimana kakao merupakan salah satu komoditas perkebunan yang memiliki peran penting dalam perekonomian nasional bahkan dunia. Berdasarkan data dari Kementerian Perdagangan (2017), Indonesia merupakan produsen biji kakao terbesar ketiga setelah Pantai Gading dan Ghana, memiliki 1.5 juta hektar luas lahan perkebunan kakao dimana dengan kontribusi sebesar $16.65 \%$ produksi kakao dunia.

Tabel 1: Sentra Produksi Kakao Dunia, Rata-Rata Tahun 2010-2014

\begin{tabular}{ccccccc}
\hline \multirow{2}{*}{ Negara } & \multicolumn{3}{c}{ Produksi (ribu ton) } & \multirow{2}{*}{ Rata-rata } \\
\cline { 2 - 6 } & $\mathbf{2 0 1 0}$ & $\mathbf{2 0 1 1}$ & $\mathbf{2 0 1 2}$ & $\mathbf{2 0 1 3}$ & $\mathbf{2 0 1 4}$ & \\
\hline Pantai Gading & 1.301 & 1.511 & 1.485 & 1.448 & 1.434 & 1.436 \\
\hline Ghana & 632 & 700 & 879 & 835 & 858 & 781 \\
\hline Indonesia & 844 & 712 & 740 & 720 & 728 & 749 \\
\hline Nigeria & 399 & 391 & 383 & 367 & 248 & 358 \\
\hline Kameroon & 264 & 240 & 268 & 275 & 269 & 263 \\
\hline
\end{tabular}

Terdapat tujuh (7) provinsi di Indonesia sebagai sentra produksi kakao, antara lain Sulawesi Tengah, Sulawesi Tenggara, Sulawesi Selatan, Sulawesi Barat,Sumatera Barat, Lampung dan Aceh, dengan kontribusi masing-masing provinsi tersebut dapat dilihat di Tabel 2. Sulawesi Tengah merupakan sentra terbesar sebesar $80.05 \%$, disusul kemudian oleh Sulawesi Tenggara dan juga Sulawesi Selatan, masing-masing sebesar $16.29 \%$ dan $16.28 \%$

Tabel 2: Sentra Produksi Kakao Di Indonesia, Rata-Rata Tahun 2013-2017

\begin{tabular}{cccc}
\hline No & Provinsi & $\begin{array}{c}\text { Rata-rata } \\
\mathbf{2 0 1 3 - 2 0 1 7}\end{array}$ & Share (\%) \\
\hline 1 & Sulawesi Tengah & 131,225 & 19.37 \\
\hline 2 & Sulawesi Tenggara & 110,399 & 16.29 \\
\hline 3 & Sulawesi Selatan & 110,316 & 16.28 \\
\hline 4 & Sulawesi Barat & 66,264 & 9.78 \\
\hline 5 & Sumatera Barat & 59,993 & 8.85 \\
\hline 6 & Lampung & 33,714 & 4.98 \\
\hline 7 & Aceh & 30,496 & 4.5 \\
\hline 8 & Lainnya & 135,146 & 19.95 \\
\hline 9 & Indonesia & 677,544 & 100 \\
\hline
\end{tabular}

Indonesia sebagai negara produsen biji kakao terbesar urutan ketiga dunia, masih mengekspor kakao dalam bentuk kakao biji atau kakao mentah yang belum mengalami proses fermentasi terlebih lagi dalam bentuk olahan lainnya, sehingga nilai atas ekspor yang didapatkan relatif kecil dibandingkan apabila mengekspor dalam bentuk olahan. Selain itu nilai tukar perdagangan yang diterima pun menjadi kecil. Pada tahun 2010, 77 persen biji kakao diekspor tanpa diolah dan sisanya baru diolah dalam negeri. Hal ini menyebabkan industri pengolahan kakao dalam negeri kekurangan bahan baku. Dalam rangka menjaga keberlanjutan produksi biji kakao sebagai sumber bahan baku industri nasional, pemerintah menerapkan kebijakan Bea Keluar komoditas biji kakao melalui Peraturan Menteri Keuangan Republik Indonesia Nomor 67/PMK.011/2010 mulai 1 April tahun 2010. Kebijakan bea cukai ini bertujuan agar terjadi pembatasan ekspor biji kakao, dan jugameningkatkanekspor kakao olahan. Setelah penerapan bea keluar biji kakao di tahun 2010 tersebut nilai ekspor biji kakao menunjukkan 
penurunan dan ekspor kakao olahan mengalami peningkatan, lihat (Gambar 1)

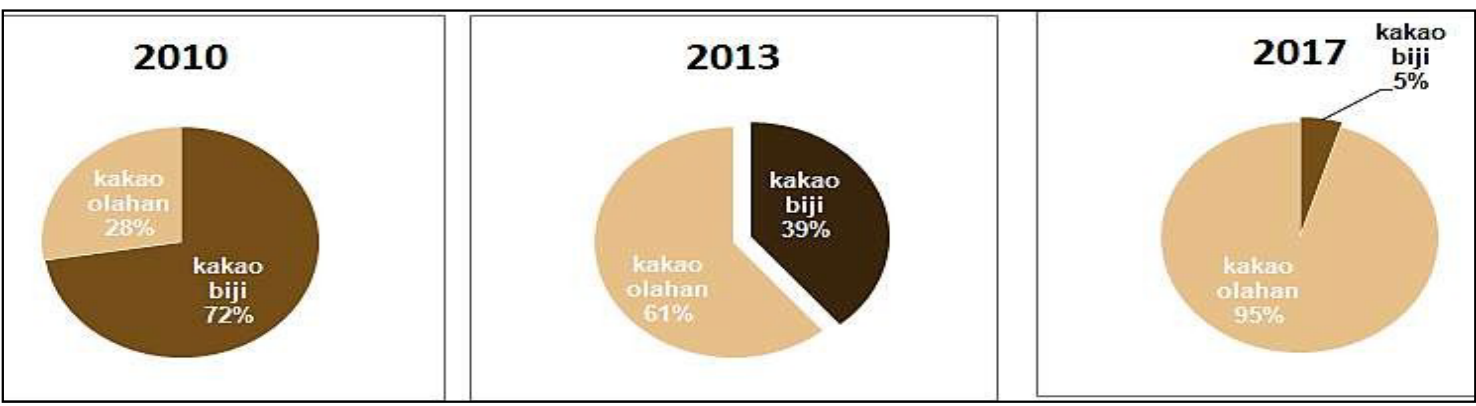

Gambar 1: Nilai ekspor produk kakao Indonesia tahun 2010, 2013 dan 2017

Sumber : UN Comtrade

Demikian halnya berdasarkan data yang diperoleh dari Kementerian Perdagangan RI, pada tahun 2012 hanya 39 persen ekspor kakao Indonesia dalam bentuk biji kakao. Angka ini menurun dibandingkan pada tahun 2008 yang mencapai 69 persen. Data tersebut menunjukkan bahwa kebijakan bea keluar telah mampu menurunkan ekspor kakao mentah (berupa biji) dan meningkatkan ekspor kakao olahan. Menurut data dari International Trade Center (2017) komoditas kakao dan produk turunannya (cocoa and other cocoa preparations) kode HS 18, dibedakan menjadi beberapa jenis kakao yaitu biji kakao (1801), kulit kakao (HS 1802), kakao pasta (HS 1803), lemak kakao (kode HS 1804), kakao powder (kode HS 1805), serta cokelat dan makanan lain yang mengandung kakao (kode HS 1806). Kakao Butter merupakan produk kakao Indonesia yang diekspor terbesar kedua setelah biji.

Dalam meningkatkan daya saing ekspor, Indonesia yaitu dengan melakukan kerjasama perdagangan diantaranya dengan negara-negara ASEAN, Australia dan New Zealand (AANZFTA). Malaysia, Australia dan Selandia Baru merupakan pasar kakao olahan Indonesia potensial. Ketiga negara kawasan AANZFTA ini mengimpor kakao olahan Indonesia berupa kakao pasta (HS 1803), kakao butter (HS 1804), dan kakao powder (1805) sejak tahun 2009 sampai 2017. Tabel 3 menunjukkan urutan ketiga negara ini sebagai peringkat 25 terbesar sebagai importir produk-produk kakao Indonesia

Tabel 3: Posisi Malaysia, Australia, dan Selandia Baru Sebagai Importir Produk Kakao Indonesia di Tahun 2017

\begin{tabular}{lcc}
\hline Negara & $\begin{array}{c}\text { Komoditi Kakao } \\
\text { Olahan (HS) }\end{array}$ & $\begin{array}{c}\text { Urutan Importir } \\
\text { Terbesar }\end{array}$ \\
\hline Malaysia & 18 & 2 \\
\hline & 1803 & 1 \\
\hline & 1804 & 6 \\
\hline & 1805 & 1 \\
\hline Australia & 18 & 8 \\
\hline & 1803 & 6 \\
\hline & 1804 & 17 \\
\hline & 1805 & 5 \\
\hline Selandia Baru & 18 & 22 \\
\hline & 1803 & 9 \\
\hline & 1804 & 18
\end{tabular}




\begin{tabular}{ccc}
\hline Negara & $\begin{array}{c}\text { Komoditi Kakao } \\
\text { Olahan (HS) }\end{array}$ & $\begin{array}{c}\text { Urutan Importir } \\
\text { Terbesar }\end{array}$ \\
\hline 1805 & 19 \\
\hline
\end{tabular}

Perkembangan ekspor produk olahan kakao ke tiga negara AANZFTA yaitu Australia, Selandia Baru, dan Malaysia berfluktuasi setelah diresmikannya perjanjian free tade area. Nilai ekspor kakao butter jauh lebih dominan dari ketiga olahan produk lainnya di negara Australia dan juga Selandia Baru, sedangkan di Malaysia kakao pasta lebih besar jumlahnya. Kakao powder dimpor paling banyak oleh negara Malaysia, disusul Australia, dan Selandia Baru. Malaysia sudah tidak banyak mengekspor biji kakao lagi karena lahan perkebunan kakao bersaing dengan kelapa sawit.
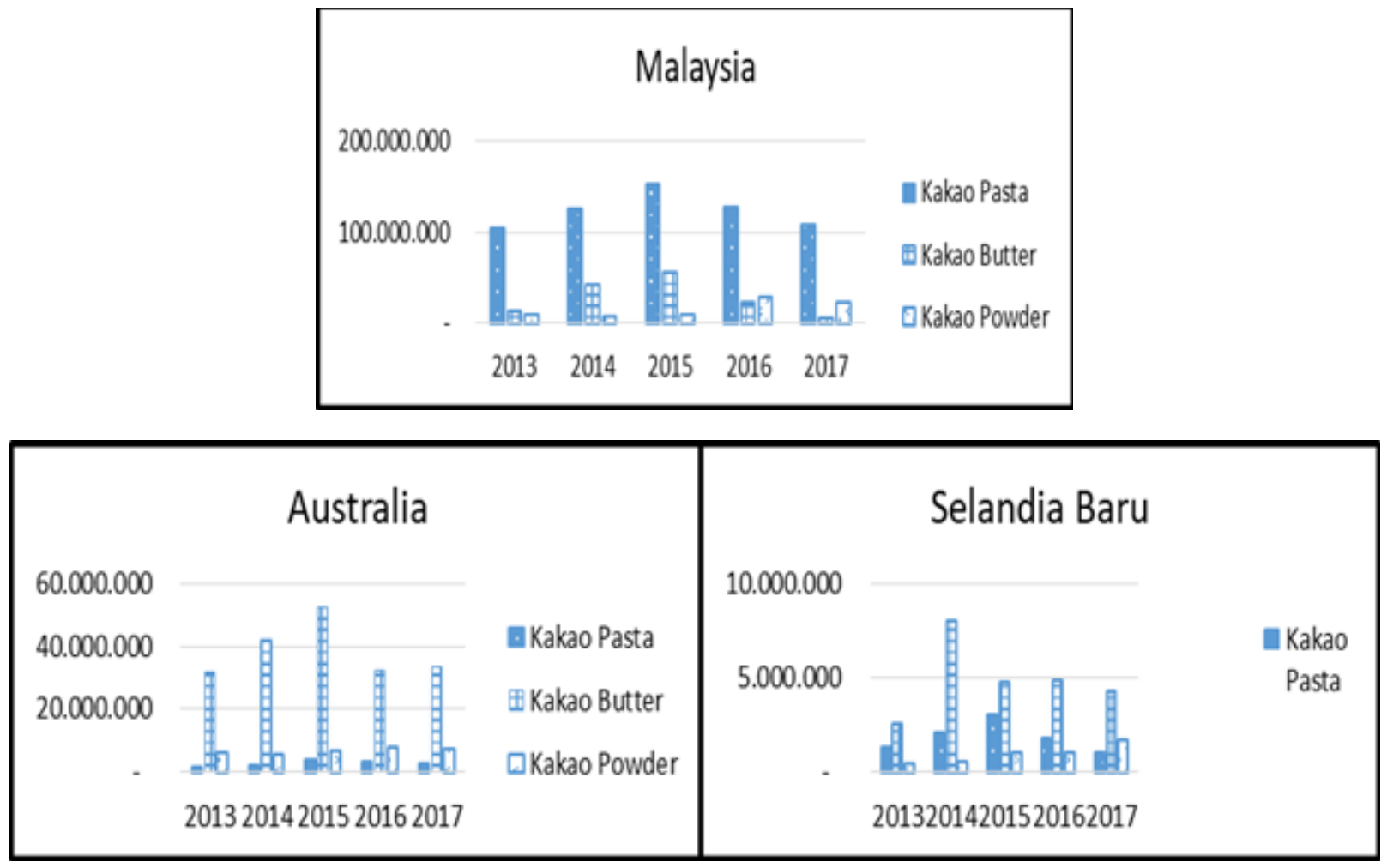

Gambar 2: Grafik Perkembangan Ekspor Kakao Olahan Indonesia 2013-2017

Sumber: UNCOMTRADE 2019 (diolah)

Pesaing utama Indonesia untuk pasar biji kakao adalah Pantai Gading dan Ghana. Salah satu pesaing Indonesia dalam eskpor kakao olahan adalah Singapura. Singapura merupakan eksportir yang utama untuk kakao pasta, kakao butter, dan kakao powder. Singapura bersaing dengan Indonesia dalam menguasai pasar Malaysia, Australia, dan Selandia Baru. Kompetitor Indonesia lainnya adalah negara Australia dalam menguasai pasar kakao powder di Selandia Baru.

Penelitian ini memiliki tujuan untuk : (1) Menganalisis daya saing serta keunggulan komparatif ekspor kakao pasta, kakao butter, dan kakao powder Indonesia di negara kawasan AANZFTA, dan (2) Menganalisis faktor-faktor yang memengaruhi permintaan ekspor kakao olahan (kakao pasta, kakao butter, dan kakao powder) Indonesia.

\section{Telaah Literatur}

\section{Daya Saing}


Menurut Simanjuntak dalam Febriyanti (2008) daya saing merupakan kemampuan suatu produsen atau negara untuk memproduksi suatu komoditi dengan biaya uang cukup rendah sehingga harga-harga yang terjadi di pasar Internasional kegiatan produksi tersebut menguntungkan. Ekspor dipengaruhi oleh adanya daya saing dengan negara-negara lain di dunia. Oleh karena itu diperlukan adanya spesialisasi komoditi sehingga seluruh negara tersebut dapat mengimpor komoditi yang telah diproduksi untuk jual dan beli. Peningkatan daya saing akan meningkatkan permintaan terhadap komoditi yang diekspor.

\section{Teori Perdagangan Internasional}

Setiap negara yang melakukan perdagangan memiliki tujuan mencari keuntungan dari kegiatan perdagangan internasional. Selain mencari keuntungan, dijelaskan Krugman (2003) mengungkapkan bahwa alasan utama terjadinya perdagangan internasional adalah:

1. Negara-negara berdagang karena mereka berbeda satu sama lain.

2. Negara-negara melakukan perdaganga dengan tujuan untuk mencapai skala ekonomi (economic of scale). Salvatore (2013) menjelaskan, Gambar 3 menunjukkan sebuah proses dari terjadinya perdagangan internasional produk kakao olahan Indonesia. Titik A pada grafik A menunjukkan posisi produksi dan konsumsi produk olahan kakao Indonesia dengan P1 sebagai posisi harga relatif produk kakao olahan Indonesia. Pada titik ini, Indonesia mengalami kelebihan penawaran atau excess supply. Pada grafik $C$, negara importir akan berporduksi dan mengonsumsi di titik $A^{\prime}$ dengan harga relatif komoditasnya di titik P3. Pada titik ini, negara impoertir mengalami kelebihan permintaan atau excess demand, sehinga melakukan permintaan pada impor. Apabila harga relatif yang berlaku di Indonesia lebih besar daripada P1, maka Indonesia akan memasok lebih banyak daripada tingkat permintaan di dalam negeri. kelebihan produksi ini akan diekspor ke negara Malaysia, Australia, dan Selandia Baru kawasan AANZFTA. Di sisi lain, jika harga relatif yang berlaku di negara importir lebih kecil dari P3, maka negara tersebut akan mengalami peningkatan permintaan, sehingga tingkat permintaan akan melebih penawaran di negara tersebut. Hal ini akan mendorong negara untuk mengimportir dari Indonesia. Grafik B menunjukkan bahwa tingkat harga pada P2 kuantitas impor yang diminta akan sama dengan kuantitas dari ekspor yang ditawarkan Indonesia. Dengan kata lain, P2 adalah harga keseimbangan relatif setelah terjadinya perdagangan internasional diantara negara tersebut.

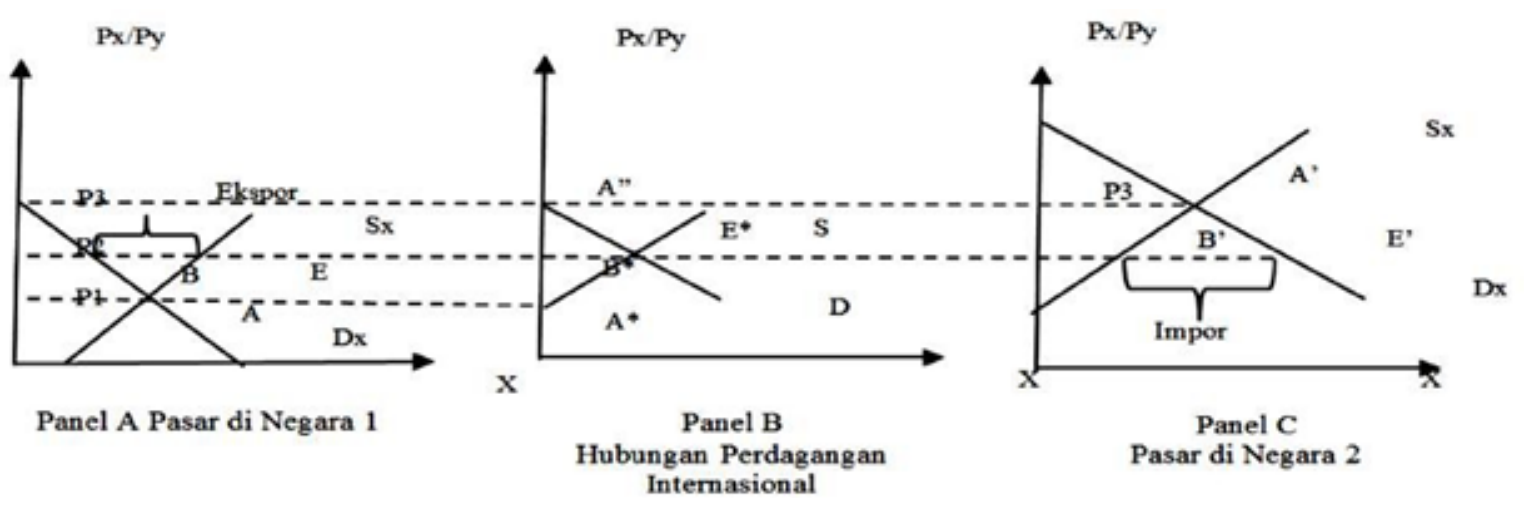

Gambar 3: Kurva perdagangan internasional

Sumber: Salvatore (2013)

\section{Teori Permintaan Ekspor}

Menurut Mankiw (2006) ekspor merupakan suatu kegiatan perdagangan yang dilaku- 
kan oleh dua negara atau lebih untuk menukarkan barang dan jasa atas dasar dari kesepatan bersama. Dari sisi permintaan, ekspor dipengaruhi oleh beberapa faktor, antara lain : (1) harga, (2) selera, (3) nilai tukar, (4) pendapatan, (5) biaya transportasi, dan (6) kebijakan pemerintah terkait perdagangan internasional.

\section{Metode}

\section{Jenis dan Sumber Data}

Data yang digunakan adalah data sekunder yang merupakan data panel, yaitu data time series (2009-2017) dan cross section (negeri- negara AABZFTA).Jenis kakao yang diteliti adalah produk turunan biji kakao yaitu kakao pasta (HS 1803), kakao butter (HS 1804), dan kakao powder (1805). Ketiga jenis kakao ini memiliki jumlah ekspor tertinggi menurut International Trade Center (2017).

\section{Metode Analisis}

Metode analisis data yang digunakan dalam penelitian ini adalah metode kuantitatif deskriptif. Metode kuantitatif dilaksanakan dengan menggunakan analisis Revealed Comparative Advantage (RCA) dan Export Dynamics Product (EPD) dan model regresi data panel. Model yang digunakan adalah :

$$
\begin{aligned}
& L n X_{i j}=\beta_{0}+\beta_{1} \ln P D B_{j}+\beta_{2} \ln E R_{j}+ \\
& \beta_{3} \ln R C A_{j}+\beta_{4} D u m m y+e_{1 i}
\end{aligned}
$$

Dimana :

$X_{i j} \quad=$ Volume ekspor kakao olahan Indonesia di negara j $(\mathrm{Kg})$

$P D B_{j}=$ PDB total negara tujuan ekspor(US \$)

$E R_{j} \quad=$ Nilai tukar Rupiah terhadap negara tujuan ekspor (Rp/domestik)

$R C A_{j}=$ Daya saing atau kinerja ekspor Indonesia terhadap negara tujuan ekspor

Dummy:

1 = sudah mulai diberlakukannya tarif 0 persen ekspor kakao olahan Indonesia (setelah perjanjian AANZFTA)

$0=$ sebelum adanya pernjanjian AANZFTA.

Hasil

Analisis Daya Saing Produk Olahan Kakao di Indonesia Periode 2013-2017Berdasarkan hasil analisis RCA selama periode 2009-2017 menunjukkan kakao olahan, baik pasta, butter powder Indonesia memiliki keunggulan komparatif di negara tujuan utama kawasan AANZFTA. Ketiga bentuk kakao olahan Indonesia memiliki keunggulan komparatif, baik di Negara Australia, Selandia Baru, dan Malaysia. Keungulan komparatif jenis kakao butter (1804) menunjukkan nilai RCA yang ternyata jauh lebih besar yang ada pada tabel Hasil analisis EPD (Gambar 4) menunjukkan bahwa kakao olahan Indonesia ke negara AANZFTA selama tahun 2009-2017 belum ada yang menempati posisi rising star. Dengan kata lain, kakao olahan Indonesia belum berada pada kondisi "bintang terang" yang menunjukkan ekspornya mengalami peningkatan dan pangsa pasar ekspor di dunia juga meningkat, namun beradapada kuadran falling star, dan retreat. Falling star mengindikasikan bahwa produk olahan kakao Indonesia memiliki pertumbuhan pangsa pasar ekspor yang positif, namun permintaan teradap produk tersebut 
justru negatif atau mengalami penurunan. Sementara pada retreat menunjukkan adanya nilai penurunan pertumbuhan pangsa pasar ekspor diikuti dengan penurunan permintaan.

Tabel 4: Nilai RCA kakao olahan Indonesia di negara AANZFTA

\begin{tabular}{|c|c|c|c|c|c|c|c|}
\hline \multirow[t]{2}{*}{ Negara } & \multirow{2}{*}{$\begin{array}{l}\text { Kode } \\
\text { Kakao }\end{array}$} & \multicolumn{5}{|c|}{ Nilai RCA } & \multirow[t]{2}{*}{ Rata-rata } \\
\hline & & 2013 & 2014 & 2015 & 2016 & 2017 & \\
\hline \multirow[t]{4}{*}{ Australia } & 1803 & 1.3 & 1.2 & 2.7 & 2.4 & 3.1 & 2.1 \\
\hline & 1804 & 23.9 & 17.3 & 24.8 & 19.1 & 30.7 & 23.1 \\
\hline & 1805 & 6.3 & 7.2 & 9.1 & 10.1 & 14.1 & 9.3 \\
\hline & 1803 & 15.4 & 26.4 & 24.4 & 20.7 & 10.5 & 19.5 \\
\hline \multirow{2}{*}{$\begin{array}{c}\text { Selandia } \\
\text { Baru }\end{array}$} & 1804 & 21.7 & 41.7 & 20.5 & 23.4 & 20.6 & 25.6 \\
\hline & 1805 & 4.5 & 6.4 & 11.8 & 12.6 & 19.3 & 10.9 \\
\hline \multirow[t]{3}{*}{ Malaysia } & 1803 & 15.3 & 17.7 & 21.7 & 21.7 & 18.9 & 19.1 \\
\hline & 1804 & 15.7 & 15.6 & 19.9 & 16.7 & 13.8 & 16.4 \\
\hline & 1805 & 4.9 & 5.5 & 8.3 & 13.8 & 16.5 & 9.8 \\
\hline
\end{tabular}

Berdasarkan Gambar 4, produk kakao pasta menempati posisi falling star di negara Australia dan Malaysia, sedangkan di negara Selandia Baru menempati posisi retreat. Untuk produk kakao buttermenempati posisiretreat di negara Australia an Malaysia, sedangkan di Selandia Baru menduduki posisi falling star. Sementata untuk kakao powder, Indonesia menduduki posisi falling star di ketiga negara. Kondisi retreat dan falling star ekspor olahan kakao Indonesia mengindikasikan diperlukan research and development, inovasi, dan strategi marketing yang lebih baik.

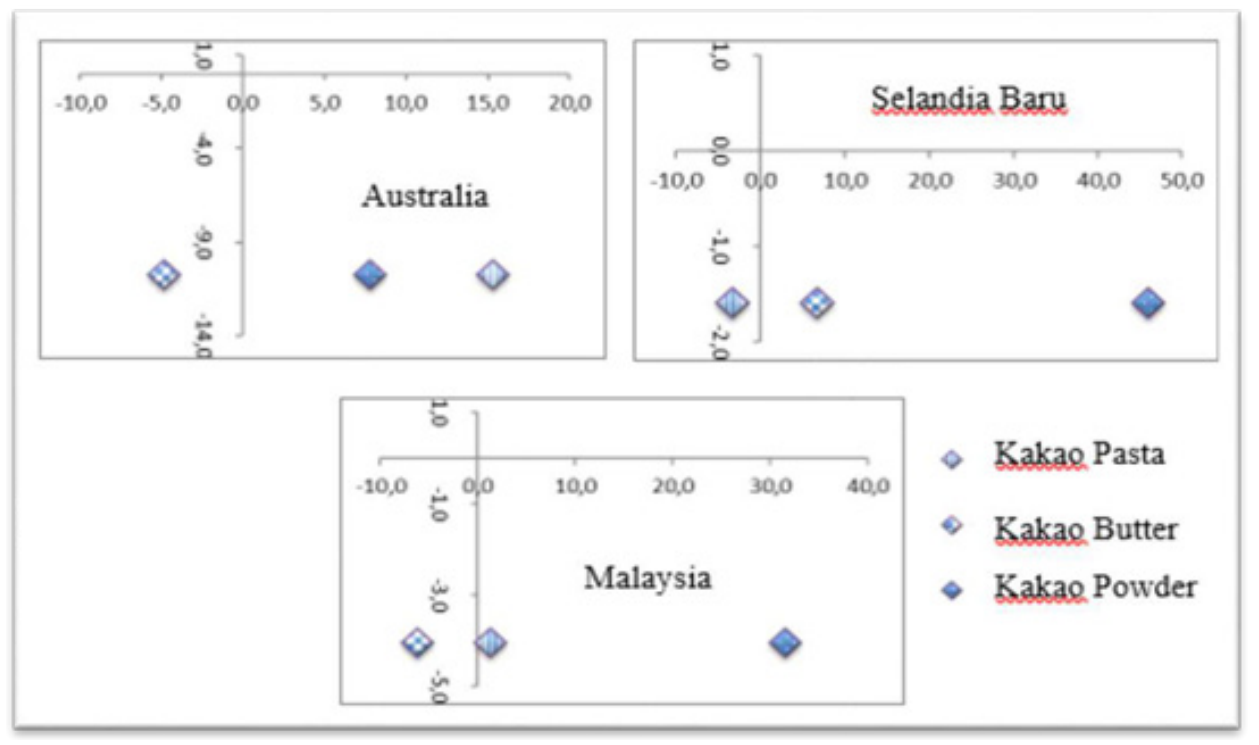

Gambar 4: Hasil EPD Olahan Kakao Indonesia Ke Negara AANZFTA

Sumber: UN COMTRADE (diolah) 2019

Estimasi Model Regresi Data Panel Ekspor Kakao Olahan Indonesia Pengujian normalitas dilakukan dengan cara melihat nilai probabilitas Jarque Bera pada histogram normality test pada Eviews. Nilai probabilitas Jarque Bera kakao pasta, kakao butter, dan kakao powder 
masing-masing lebih besar dari tarif nyata lima persen, sehingga dapat disimpulkan bahwa asumsi kenormalan sudah terpenuhi. Pengujian adanya masalah heteroskedasitas dilakukan dengan membandingkan nilai sum squared resid sebelum dan setelah dibobotkan. Dimana jika ditemukan bawha sum square resid setelah dibobotkan lebih rendah daripada setelah dibobotkan maka dapat disimpulkan bahwa model terbebas dari permasalahan heteroskedasitas. Pada uji heteroskedasitas kakao pasta, kakao butter, dan kakao powder menunjukkan bahwa masalah heteroskedasitas tidak ditemukan.

Nilai Durbin-watson pada kakao pasta, kakao butter, dan kakao powder masing-masing sebesar 1.755, 2.073, dan juga 2.066. Berdasarkan hasil tabel Durbin-Watson, ketiga model ini juga sudah terbebas dari masalah autokolinearitas. Masing-masing korelasi variabel bebas dari masalah multikolinearitas, karena menurut dari Gujarati (2006) model terbebas dari masalah multikolinearitas jika memiliki nilai kolinearitas lebih kecil dari 0.8 .

Permodelan yang dipakai untuk regresi data panel pada penelitian ini adalah model Pooled OLS. Berdasarkan hasil uji chow yang dilakukan menunjukkan nilai probabilitas cross section $\mathrm{F}$ dimana nilai tersebut lebih besar dari 0.05 yang mengindikasikan model Pooled OLS adalah model terbaik untuk regresi. Ketiga model memiliki probabilitas $\mathrm{F}$ statistic lebih kecil dari taraf nyata 0.05 yang menunjukkan bahwa variabel-variabel bebas dalam model secara bersama-sama memiliki pengaruh nyata atau minimal terdapat satu variabel bebas yang berpengaruh nyata terhadap variabel terikatnya.

Nilai R-square dari masing-masing estimasi model kakao pasta, kakao butter, dan kakao powder sebesar $0.932428,0.950771$, dan 0.981710 yang berarti mengindikasikan bahwa variabel bebas yang digunakan dalam model dapat menjelaskan variasi perubahan sebesar 93.2 persen (kakao pasta), 95.1 persen (kakao butter), 98.1 persen (kakao powder) dan sisanya dijelaskan oleh variabel bebas lainnya yang tidak tercantum dalam model.

\section{Kakao Pasta}

Berdasarkan hasil uji pada Tabel 5, dapat diketahui bahwa indikator dayasaing (RCA), nilai tukar, dan dummy yang berpengaruh siginifikan. Tingkat dayasaing kakao pasta ke negara kawasan AANZFTA berpengaruh secara signifikan terhadap permintaan kakao pasta Indonesia di beberapa negara kawasan AANZFTA. Nilai koefisien tingkat dayasaing pada model menunjukkan angka sebesar 0.900250 dan memiliki korelasi positif.

Artinya, setiap kenaikan tingkat daya saing sebesar 1 persen maka permintaan kakao pasta di berbagai negara kawasan AANZFTA meningkat sebesar $85 \%$, ceteris paribus. Hal ini sejalan dengan penelitian Nugroho (2018) yang menyatakan bahwa apabila daya saing suatu produk semakin tinggi di pasar internasional maka permintaan akan produk tersebut juga akan semakin tinggi sehingga volume ekspornya meningkat. Nilai tukar rupiah terhadap permintaan berpengaruh negatif signifikan. Artinya setiap apresiasi rupiah sebesar 1 persen akan menurunkan permintaan ekspor kakao pasta Indonesia sebesar $1.73 \%$. Sementara dummy CEPTAANZFTA berpengaruh positif sebesar 0.3193 yang mengindikasikan bahwa adanya FTA AANZ mengakibatkan adanya kenaikan sebesar $31 \%$.

Tabel 5: Hasil Estimasi Regresi Data Panel Kakao Pasta

\begin{tabular}{ccc}
\hline Variabel & Koefisien & Probabilitas \\
\hline Konstanta & -9.574723 & 0.0000 \\
\hline PDB & 1.369876 & 0.3676 \\
\hline
\end{tabular}




\begin{tabular}{|c|c|c|c|}
\hline Variabel & \multicolumn{2}{|c|}{ Koefisien } & Probabilitas \\
\hline ER & \multicolumn{2}{|c|}{-1.736758} & 0.0000 \\
\hline RCA & \multicolumn{2}{|c|}{0.900250} & 0.0000 \\
\hline DUMMY & \multicolumn{2}{|c|}{0.319330} & 0.0117 \\
\hline \multicolumn{4}{|c|}{ Statistik dengan pembobotan } \\
\hline R-squared & 0.932428 & Sum squared resid & 5.618461 \\
\hline Adjusted R-squared & 0.920142 & Durbin-Watson stat & 1.755807 \\
\hline F-Statistic & \multicolumn{3}{|l|}{75.89492} \\
\hline Prob (F-Statistic) & \multicolumn{3}{|l|}{0.000000} \\
\hline \multicolumn{4}{|c|}{ Statistik tanpa pembobotan } \\
\hline R-squared & 0.888706 & Durbin-Watson stat & 1.479415 \\
\hline Adjusted R-squared & 6.094415 & & \\
\hline
\end{tabular}

\section{Kakao Butter}

Berdasarkan hasil uji padaTabel 6, dapat diketahui bahwa nilai tukar, dummy kebijakan diresmikannya perjanjian AANZFTA, dan PDB importir berpengaruh signifikan terhadap permintaan ekspor kakaobutter di kawasan negara AANZFTA. Nilai tukar berpengaruh negatif signifikan sebesar 0.683355 . Artinya, setiap peningkatan nilai tukar sebesar 1 persen, maka akan bisa menurunkan volume permintaan ekspor kakao butter Indonesia sebesar $0.68 \%$. Dummy nilai dari kerjasama AANZFTA berpengaruh secara signifikan dan positif terhadap permintaan kakao butter. Nilai dari koefisien dummy pada model menunjukkan angka sebesar 0.4256 . Hal ini menunjukkan bahwa perjanjian AANZFTA menaikkan permintaan sebesar $0.42 \%$. Demikian halnya dengan PDB total negara importir berpengaruh secara positif signifikan terhadap permintaan ekspor kakao pasta di kawasan AANZFTA. Artinya, setiap kenaikan PDB sebesar $1 \%$ akan meningkatkan jumlah permintaan ekspor kakao pasta di kawasan AANZFTA sebesar $1.253 \%$. Dummy atas kerjasama AANZFTA terutama terkait bea cukai keluar kakao olahan Indonesia berpengaruh positif signifikan terhadap permintaan kakao butter. Nilai koefisien dummy pada model menunjukkan angka sebesar 0.4256 . Hal ini menunjukkan bahwa perjanjian AANZFTA menaikkan demand kakao butter sebesar $42 \%$.

\section{Tabel 6: Hasil Estimasi Regresi Data Panel Kakao Butter}

\begin{tabular}{ccc}
\hline Variabel & Koefisien & Probabilitas \\
\hline Konstanta & -13.44492 & 0.0091 \\
\hline PDB & 1.253996 & 0.0000 \\
\hline Dummy & 0.425625 & 0.0042 \\
\hline RCA & 0.014875 & 0.3774 \\
\hline ER & \multicolumn{4}{c}{0.683355} \\
\hline AR(1) & 0.125056 \\
\hline R-squared & Statistik dengan pembobotan & 0.5949 \\
\hline Adjusted R-squared & 0.950771 & Sum squared \\
\hline F-Statistic & resid & 2.997629 \\
\hline Prob (F-Statistic) & 0.937097 & Durbin-Watson \\
\hline & & stat \\
\hline
\end{tabular}




\begin{tabular}{cccc}
\hline Variabel & Koefisien & Probabilitas \\
\hline R-squared & 0.870256 & $\begin{array}{c}\text { Durbin-Watson } \\
\text { stat }\end{array}$ & 1.551242 \\
\hline Adjusted R-squared & 3.289326 & & \\
\hline
\end{tabular}

Tabel 7: Hasil Estimasi Regresi Data Panel Kakao Powder

\begin{tabular}{|c|c|c|c|}
\hline Variabel & Koefisien & & Probabilitas \\
\hline Konstanta & & -0.516567 & 0.6120 \\
\hline PDB & & 1.197416 & 0.0000 \\
\hline Dummy & & 0.558252 & 0.0000 \\
\hline RCA & & 0.798659 & 0.0000 \\
\hline ER & & -2.198169 & 0.0000 \\
\hline \multicolumn{4}{|c|}{ Statistik dengan pembobotan } \\
\hline R-squared & 0.981710 & Sum squared resid & 0.693932 \\
\hline Adjusted R-squared & 0.978385 & Durbin-Watson stat & 2.066227 \\
\hline F-Statistic & 295.2174 & & \\
\hline Prob (F-Statistic) & 0.000000 & & \\
\hline \multicolumn{4}{|c|}{ Statistik tanpa pembobotan } \\
\hline R-squared & 0.982826 & Durbin-Watson stat & 2.078326 \\
\hline Adjusted R-squared & 0.716403 & & \\
\hline
\end{tabular}

Berdasarkan hasil uji pada Tabel 7, dapat diketahui bahwa variabel independennya yaitu, dummy kerjasama AANZFTA, RCA, PDB total, dan nilai tukar memiliki pengaruh yang signifikan. Dummy yang mengisyarakan kerjasama AANZFT memiliki pengaruh secara signifikan positif terhadap permintaan kakao powder di negara kawasan AANZFTA. Nilai koefisien dummy yang ada pada model menunjukkan angka sebesar 0.5558252. Hal ini menunjukkan bahwa adanya kerjasama AANZFTA mampu meningkatkan permintaan kakao powder $0.55 \%$ dibandingkan sebelum adanya kerjasama AANZFTA. Tingkat daya saing kakao powder ke negara kawasan AANZFTA memiliki pengaruh positif serta signifikan terhadap permintaan kakao powder Indonesia dengan nilai koefisien sebesar 0.798659. Artinya, setiap kenaikan tingkat daya saing sebesar 1 persen maka nilai permintaan kakao powder Indonesia di negara kawasan AANZFTA akan meningkat sebesar $0.79 \%$, ceteris paribus. Nilai tukar negara importir terhadap rupiah berpengaruh negatif signifikan terhadap permintaan ekspor kakao powder di kawasan AANZFTA dengan koefisien 2.19816. yang berarti, setiap peningkatan nilai tukar rupiah terhadap negara importir sebesar 1 persen, akan dapat menurunkan volume pada permintaan ekspor kakao powder Indonesia sebesar $2.19 \%$.

\section{Simpulan}

Hasil analisia daya saing menggunakan RCA menunjukkan bahwa semua kakao olahan Indonesia yaitu kakao pasta, butter dan powder memiliki daya saing di Negara Malaysia, Australia, dan Selandia Baru. Semantara dilihat dari hasil analisis daya saing dinamis dengan menggunakan EPD menunjukkan belum adanya produk olahan kakao Indonesia yang berada pada posisi rising star. Kakao pasta berada pada kuandranfalling star di negara Australia, dan Malaysia, dan berada pada posisi retreat di Selandia Baru. Sementara daya saing kakao butter, berada dalam posisi retreat di negara Australia dan Malaysia, dan falling star di Selandia Baru. 
Untuk kakao powder, hasil EPD menunjukkandaya saing di ketiga negara berada dalam posisi falling star.

Hasil analisis regresi data panel menunjukkan variabel yang berpengaruh signifikan terhadap tingkat dayasaing ekspor bentuk kakao olahan adalah nilai tukar dan dummy kebijakan Kerjasama AANZFTA.

\section{Saran}

Pemerintah dan perusahaan produsen kakao olahan perlu meningkatkan research and development terkait produksi biji kakao sampai menjadi kakao olahan, sebagai upaya untuk meningkatkan daya saing komoditas olahan kakao Indonesia. Perlu memperkuat kerjasama yang saling menguntungkan antara petani dan industri pengolahan kakao. Selain itu perlu upaya memperkuat kerjasama Indonesia dengan AANZFTA tidak hanya dalam bidang perdagangan, tetapi juga dalam hal investasi dan riset.

\section{Daftar Pustaka}

Al Ghozy, M.R., Soelistiyo, A. and Kusuma, H., (2017). Analisis Ekspor Kakao Indonesia di Pasar Internasional. Jurnal IImu Ekonomi JIE, 1(4), hh.453-473.

Badan Pusat Statistika. (2015). Statistika Indonesia. Jakarta (ID): Diakses dari http://Badan Pusat Statistik. co. id.

Badan Pusat Statistika. (2018). Analisa Komoditi Ekspor, 2010-2017, Sektor Pertanian, Industri, dan Pertambangan. [diunduh 13 Februari 2019]. Diakses dari https://www.bps.go.id/ publication/

Juanda, B., (2009). Ekonometrika pemodelan dan pendugaan. Bogor: IPB Pres.

Evelina M. (2018). Analisis Daya saing Olahan Kakao Indonesia di Negara Tujuan Utama Ekspor setelah Penetapan Tarif Ekspor. Skripsi Institut Pertanian Bogor.

Febriyanthi, Sri Ana. (2008). Analisis Daya Saing Ekspor Teh Hitam Indonesia di Pasar Internasional [skripsi]. Fakultas Pertanian. IPB. Bogor.

Gujarati, N Damodar. (2001). Ekonometrika Dasar. Cetakan keenam. Jakarta: Erlangga.

International Cocoa Organization. (2017). Quarterly Bulletin of Cocoa Statistics. Diakses dari http://www.icco.org. pada, 1 Februari 2019

International Trade Center. (2017). International Trade in Goods - Exports. Diakses dari http:// www.trademap.org pada 1 Februari 2017

Kementrian Perdagangan. (2017). Data dan Statistik. Jakarta.

Kementerian Pertanian. (2017). Outlook 2017: Komoditas Pertanian SubSektor Perkebunan diakses dari http://epublikasi.setjen.pertanian.go.if pada, 10 Januari 2019

Krugman, P dan O, Maurice. (2003). Ekonomi Internasional Teori dan Kebijakan. Edisi Kelima. Jakarta: PT Indeks Kelompok Gramedia.

Lipsey, R. G. (1995). Pengantar Mikroekonomi Edisi Kesepuluh Jilid Dua. A. J Wasana, Kibrandoko, Budijanto, penerjemah. Jakarta: Binarupa Aksara..

Mankiw, G. (2006). Makroekonomi. Liza F, Nurmawan I, penerjamah; Hardani W, Barnadi 
D,Saat S,editor. Jakarta: Erlangga.

Nachrowi, D. (2006). Ekonometerika, untuk Analisis Ekonomi dan Keuangan, Cetakan Pertama. Jakarta: Lembaga Penerbit FE UI.

Nugroho, B. S. (2018). Analisis Daya Saing Sektor Pariwisata dan Kontribusi terhadap PDRB Kabupaten Bondowoso [skripsi]. Fakultas Ekonomi dan Bisnis. Universitas Jember. Jember.

Oktaviani, R. dan Tanti, N. (2009). Teori Perdagangan Internasional dan Aplikasinya di Indonesia. Bogor: Departemen Ilmu Ekonomi, Fakultas Ekonomi dan Manajemen, Institut Pertanian Bogor.

Organization, I. C. (2019). 1995-2015, International Cocoa Organization.

Penetapan Peraturan Menteri Keuangan Republik Indonesia Nomor 67/PMK.011/2010 tentang Tarif Biaya Keluar Biji Kakao Indonesia.

Peraturan Presiden Nomor 26 Tahun 2011 tentang Pengesahan Agreement Establishing The ASEAN-Australia-New Zealand Free Trade Area

Salvatore, D. (2013). International Economics 11th Edition. New York: R. R. Donelley-JC.

Sitanggang, V. (2009). Analisis Faktor-Faktor yang Mempengaruhi Permintaan Ekspor Biji Kakao Indonesia di Malaysia, Singapura, Thailand dalam Skema CEPT- AFTA. Skripsi. Bogor: Institut Pertanian Bogor.

United Nations Commodity Trade Statistic. (2019). Commodity Trade. Diakses dari http://comtrade.un.org pada Januari 2019. 